\title{
Evaluation of the frequency of Candida spp. in hospitalized and non-hospitalized subjects
}

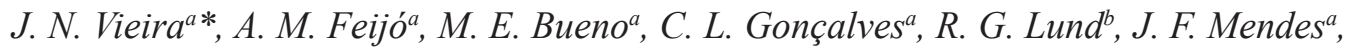 \\ J. P. V. Villarreal ${ }^{a}$, M. M. Villela ${ }^{a}$ and P. S. Nascente ${ }^{a}$ \\ ${ }^{a}$ Laboratório de Parasitologia, Instituto de Biologia, Departamento de Microbiologia e Parasitologia, Universidade Federal \\ de Pelotas - UFPEL, Campus universitário Capão do Leão, s/n, Prédio 18, Sala 3, CEP 96010-900, Pelotas, RS, Brazil \\ ${ }^{b}$ Departamento de Odontologia Restauradora, Faculdade de Medicina Dentária, Universidade Federal de Pelotas - UFPEL, \\ Rua Gonçalves Chaves, nº 457, Centro, CEP 96020-080, Pelotas, RS, Brazil \\ *e-mail: jujununesvieira@yahoo.com.br
}

Received: December 19, 2016 - Accepted: May 27, 2017 - Distributed: November 30, 2018

\begin{abstract}
The aim of this study was to evaluate the frequency of Candida species between a non-hospitalized and a hospitalized population. For this purpose, samples of saliva were sampled through sterile swabs, moistened in peptone water and rubbed in the oral cavity of 140 individuals, from which, 70 were hospitalized patients from the Medical Clinic of a Teaching Hospital and the other 70 were non-hospitalized subjects. All saliva samples were plated in Sabouraud Dextrose agar added with Chloramphenicol and incubated at $36{ }^{\circ} \mathrm{C}$ for 48 hours. The morphology identification was performed through macroscopic and microscopic characterization, the CHROMagar Candida medium and the VITEK $^{\circledR}$ system Yeast Biochemical Card (bio Mérieux SA, France). The results showed a colonization of Candida spp. in $85.7 \%$ the hospitalized individuals, where the species found were C. albicans (60\%), C. tropicalis (23.4\%), C. krusei (3.3\%) and Candida spp. (13.3\%). In the non-hospitalized individuals the colonization by Candida spp was $47.1 \%$, and the species found were: C. albicans (45.5\%), C.krusei (9.1\%), C. guilliermondii (9.1\% \%), C. tropicalis $(3.0 \%)$, . famata $(3.0 \%)$ and Candida spp. (30.3\%). In spite of their presence in oral cavity in both groups, Candida spp. was more frequently isolated in hospitalized individuals, who were 6.73 times more likely to have this fungus in the oral cavity and were 3.88 times more likely to have Candida albicans.
\end{abstract}

Keywords: Oral Candida spp., colonization, hospitalized patients, nosocomial infections.

\section{Avaliação da frequência de candida spp. em indivíduos hospitalizados e não hospitalizados}

\section{Resumo}

O objetivo deste estudo foi avaliar a frequência de espécies de Candida entre uma população de indivíduos não-hospitalizados e hospitalizados. Para isto, amostras de saliva foram coletadas através de swabs estéreis, umedecidas em água de peptona e friccionadas na cavidade bucal de 140 indivíduos, dos quais 70 eram pacientes internados em uma Clínica Médica de um Hospital Escola e os outros 70 eram indivíduos não hospitalizados sem contato com ambiente hospitalar. Todas as amostras de saliva foram plaqueadas em ágar Sabouraud dextrose adicionadas de cloranfenicol e incubadas a $36^{\circ} \mathrm{C}$ durante 48 horas. A identificação morfológica foi realizada através da caracterização macroscópica e microscópica, com o meio CHROMagar Candida e do sistema VITEK ${ }^{\circledR}$ Biochemical Card (bio Mérieux SA, França). Os resultados mostraram uma colonização de Candida spp. em 85,7\% dos indivíduos hospitalizados, onde as espécies encontradas foram: C.albicans (60\%), C. tropicalis $(23,4 \%)$, C. krusei $(3,3 \%)$ e Candida spp. (13,3\%). Nos indivíduos não-hospitalizados a colonização por Candida spp foi de 47,1\%, e as espécies encontradas foram: C. albicans (45,5\%), C. krusei (9,1\%), C. guilliermondii (9,1\%), C. tropicalis (3,0\%), C. famata (3,0\%) e Candida spp. (30,3\%). Apesar de sua presença na cavidade oral em ambos os grupos, Candida spp. foi mais freqüentemente isolada em indivíduos hospitalizados, que foram 6,73 vezes mais propensos a ter este fungo na cavidade oral e foram 3,88 vezes mais propensos a ter Candida albicans.

Palavras-chave: Candida spp. oral, colonização, pacientes hosptalizados, infecções hospitalares. 


\section{Introduction}

The yeasts of Candida species are microorganisms of the oral microbiota of humans, in which colonization occurs immediately after birth. This microbiological condition usually offers a harmonious balance between the parasite and the host, maintaining the immune system and keeping the integrity of tissue barriers. This balance, however, may be disrupted due to a low immunity or by a mechanical, physical and iatrogenic change in the oral cavity, compromising the immune system and facilitating endogenous opportunistic infections caused by Candida spp. (Ribeiro et al., 2006; Moyes and Naglik, 2011; Simões et al., 2013). Thus, Candida spp. virulence may present pathogenic action when the host's resistance is overcome (Santana et al., 2013).

Opportunistic nosocomial infections are more frequent and severe in patients with poor oral health care, as well those who have been exposed to long intensive drug therapies. Some authors have stated that hospitalized patients tend to develop a higher oral candidiasis prevalence, due to both local and systemic alterations, changing the microbiota and contributing to this kind of infections (Grimoud et al., 2003; Meurman and Hamalainen, 2006; Moris et al., 2008). In addition, many intrinsic and extrinsic factors influence the composition, metabolic activity and pathogenicity of a variety of microorganisms in the oral cavity (Bodineau et al., 2009).

Hospital-acquired infections caused by yeasts may have an exogenous source, and are generally transmitted by the hands of health professionals, surfaces of materials, lab coats of health care practitioners (Savastano et al., 2016) and by people getting in contact with the patient, or by an endogenous source, such as the pre-existing microorganisms in the host, turning pathogenic for some reason. In view of the above, the aim of the present paper was to verify the occurrence and frequency of the yeasts of Candida spp., in the oral cavity of both non-hospitalized subjects and hospitalized patients from a Medical clinic of a Teaching Hospital situated in the city of Pelotas, Rio Grande do Sul.

\section{Material and Methods}

\subsection{Individuals and sampling}

A total of 140 subjects took part in this study; they were divided in two groups. One group of 70 patients were under hospitalization in the Federal University Hospital of Pelotas, and the second group of 70 non-hospitalized subjects, were mainly students and professionals from the same University; none of the 140 subjects presented oral lesions.

The evaluation was based on a questionnaire where the non-hospitalized subjects also declared that they did not carried any infectious diseases at the time of sampling nor in the preceding month; they also declared that they did not have any underlying diseases, they had not been submitted to antibiotic and corticoid therapy in the six months previous to evaluation, and had no contact with hospitalized patients who participated in this study. These individuals age ranged between $18-75$ years.

From 70 hospitalized patients, 50 had some type of bacterial infection and underwent antibiotic therapy at the most one month ago, and 20 were submitted to cancer treatment; their age ranged of 19-86 years. The hospitalized patients with cancer were submitted to the same type of chemotherapy, in the General Medical Clinic of the hospital, between one week and one month of hospitalization. The collections were always performed after the chemotherapy.

This research was approved by the Research Ethics Committee of the Federal University of Pelotas (UFPel), under registration CEP 48/10, and the participants signed an Informed Consent Agreement.

The sampling was performed from the mucosa of the cheek in the oral cavity, through sterile swabs, moistened in peptone water. Each sample was identified with the corresponding number of the clinical report within the information of the patient. The reports were referred, along with the sampled material, to the Laboratory of Mycology of the Biology Institute from the UFPel.

\subsection{Identification of yeasts}

The samples were plated in Sabouraud Dextrose agar added with Chloramphenicol and incubated at $36{ }^{\circ} \mathrm{C}$ for 48 hours. The macro morphology was analysed by Gram-stain smears observed by light microscopy (1000X), followed by the germ tube test and micro culture in cornmeal media. After, the samples were replicated in CHROMagar Candida medium for an initial differentiation of the species (Araújo et al., 2005; Mímica et al., 2009). Unidentified isolates were evaluated through the assimilation of carbohydrates by the Vitek ${ }^{\circledR}$ system Yeast Biochemical Card (bio Mérieux SA, France) (Spolidorio et al., 2009; Gonçalves et al., 2015).

\subsection{Statistical analysis}

A descriptive comparison of both study groups (hospitalized patients and non-hospitalized subjects) of different variables was developed, expressing frequency (value - n) and percentages (\%) values. The statistical tests between the groups was performed using the chi-square test $(\mathrm{p} \leq 0.05)$, and the evaluation of the odds ratio (OR) with $95 \%$ of confidence intervals $\left(\mathrm{CI}_{95 \%}\right)$.

This research was approved by the Research Ethics Committee of the Federal University of Pelotas (UFPel), according to the Declaration of Helsing, and the participants signed an Informed Consent Agreement.

\section{Results}

Candida isolates were found in 33 (47.1\%) of the 70 samples from the non-hospitalized individuals. The species isolated were: C. albicans in 15 (21.4\%) individuals; C. krusei in three (4.3\%); C. Guilliermondii in three $(4.3 \%)$; C. tropicalisin one $(1.4 \%)$; C. famatain one (1.4\%), and $10(14.3 \%)$ were identified as Candida spp. 
Table 1. Frequency of Candida spp. and Candida albicans in hospitalized $(\mathrm{n}=70)$ and non-hospitalized individuals $(\mathrm{n}=70)$ from the city of Pelotas, Rio Grande do Sul state, Brazil.

\begin{tabular}{|c|c|c|c|c|}
\hline Variables & $\frac{+}{\text { n (\%) }}$ & $\frac{-}{\text { n (\%) }}$ & p-value & $\mathrm{OR}\left(\mathrm{CI}_{95 \%}\right)$ \\
\hline \multicolumn{5}{|l|}{ Presence of Candida spp. } \\
\hline Hospitalized & $60(85.7)$ & $10(14.3)$ & $<0.0001$ & 6.73 \\
\hline Non-hospitalized individuals & $33(47.1)$ & $37(52.9)$ & & $(2.97-15.24)$ \\
\hline \multicolumn{5}{|l|}{ Presence of Candida albicans } \\
\hline Hospitalized & $36(51.4)$ & $34(48.6)$ & $<0.0001$ & 3.88 \\
\hline Non-hospitalized individuals & $15(21.4)$ & $55(78.6)$ & & $(1.85-8.13)$ \\
\hline
\end{tabular}

Candida spp. was isolated in $60(85.7 \%)$ from the 70 samples of the hospitalized patients. The identified species were: C. albicans in 36 (51.4\%) samples; C. tropicalis in 14 (20\%) samples; C. krusei in two (2.9\%), and Candida spp. in eight (11.4\%). From patients hospitalized due to cancer chemotherapy (20 individuals), 14 were positive for fungus $(70 \%)$ and $C$. albicans was isolated in eleven of the samples from these patients and Candida spp. in three. Yeasts were isolated in 46 (92\%) of the 50 samples from patients undergoing antibiotic therapy due to infection $\left(\mathrm{p}\right.$-value $\left.=0.017, \mathrm{OR}=4.93, \mathrm{CI}_{95 \%}=1.22-19.99\right)$. Of these 46 samples, 25 (54.3\%) were by Candida albicans.

Bacterial diseases and the location of tumors were not considered as a whole for a disease that can be statistically analyzed for characteristics.

In both groups, no mixed colonization by Candida species was detected, only individual mono colonization occurred in the analyze. A statistical significant difference ( $p$-value $<0.0001$ ) was observed in the isolation of the yeast from oral cavity in both groups included in this study - non-hospitalized individuals and hospitalized patients from the Medical Clinic (Table 1). Hospitalized patients were 6.73 (p-value $<0.0001, \mathrm{CI}_{95 \%}=2.97-15.24$ ) times more likely to have Candida spp., and 3.88 (p-value $<0.0001$, $\mathrm{CI}_{95 \%}=1.85-8.13$ ) times more likely to have $C$. albicans compared to the non-hospitalized subjects.

\section{Discussion}

Candida species live as commensals and are part of the normal microbiota of healthy subjects. A great variety of microorganisms with the ability of moving out and reintroducing themselves rapidly into the human system are regularly found in the oral cavity. This relation of microbial coexistence with the human health is possible by the immunological mechanisms through a continuous process of adaptation (Bodineau et al., 2009; Moyes and Naglik, 2011; Naglik and Moyes, 2011). Fungal infections have increased in recent years, and are responsible for high morbidity and mortality rates. Candida still causes most of the fungal nosocomial infections; the presence of these yeasts in human microbiota favours the incidence of these infections, mainly due to the virulence factors of the fungus and its interaction with the hospitalized patients who presented a weak immune system (Hinrichsen et al., 2009; Heo et al., 2011; Silva et al., 2014)

In this study, Candida spp. was found in $47.1 \%$ of the non-hospitalized subjects, and this agrees with other studies showing a 10 to $70 \%$ variation of Candida spp., in healthy individuals (Motta et al., 2010). 47.3\% of positivity of Candida spp. in the oral cavity was also found in a group of children of a school from different socioeconomic status without candidiasis lesions, in which C. albicanswas the prevailing specie, corresponding to $95 \%$ of all the isolates (Moreira et al., 2001). Yeasts of Candida play an extremely important role in high frequent infections and colonization in humans (Moris et al., 2008; Lass-Flörl, 2009; Savastano et al., 2016). These findings agrees with the reported by several authors related to the colonization prevalence of $C$. albicans over other species in the oral cavity, and consequently on the subsequent candidiasis development (Moreira et al., 2001; Grimoud et al., 2003; Naglik et al., 2003; Moris et al., 2008; Moyes and Naglik, 2011).

The yeast was isolated from the hospitalized patients in $85.7 \%$, being twice the frequency observed in the non-hospitalized individuals. The isolated species were: C. albicans, C. tropicalis, C. krusei and Candida spp. The most frequent isolated specie was again C. albicans, found in $51.4 \%$ of the patients. C. albicansis without a doubt the most frequently isolated specie in both superficial and invasive infections from different anatomic sites, and the most common cause of candidiasis and candidemia worldwide (Moris et al., 2008; Hinrichsen et al., 2009; Savastano et al., 2016).

A study performed by Domaneschi et al. (2011) revealed the prevalence of Candida spp., in the oral cavity of immunocompromised patients (aids paediatric patients), and found it in $62 \%$ of the analysed samples and the most frequent isolated specie in this study was $C$. albicans. Another study by St-Germain et al. (2008), in which a total of 453 episodes of candidemia from 54 laboratories from hospitals in Quebec, Canada, founded Candida albicans in $62 \%$ of the isolates, and the authors reported that in North America and in most countries worldwide, C. albicans continues to be the single most common specie causing candidemia.

The presence of yeasts of Candida spp. on human skin and mucosa, facilitates the occurrence of oral or systemic 
candidiasis (Moris et al., 2008). The virulence factors of the fungus and the immune status of the individual are two parameters which controls the onset of Candida spp. (Hube, 2004; Pfaller and Diekema, 2007). The occurrence of nosocomial infections is a worrying factor, once it is directly connected to the onset of resistant infections in most of the cases (Soll et al., 2003; Cantón et al., 2006).

The fact that the hospitalized patients undergoing antibiotic therapy had a higher significant prevalence of Candida spp,. (p value $=0.017)$, deserves attention. This fact was verified by other authors; however, this prevalence can depend of the quantity of administrated antibiotics per day, type of drug used (mainly those with broad spectrum), the length of treatment, the Candida specie (C. albicans or non-albicans Candida species), among others (Krcmery Junior et al., 1998; Singh, 2001; Al Thaqafi et al., 2014).

Commensal microorganisms become pathogenic due to alterations in the host defence mechanisms (immunosuppression), or in the secondary anatomical barriers - such as burns or invasive medical procedures. Alterations in the host defence mechanisms may also result from physiological changes in childhood (prematurity), aging, often associated with degenerative, congenital or acquired immune deficiencies, as well as hospitalizations or immune depression induced by medical action (Bodineau et al., 2009; Lund et al., 2010; Moyes and Naglik, 2011; Savastano et al., 2016). Therefore, the importance of knowing the microorganisms that are part of the microbiota of patients with a differentiated immune condition.

From the patients diagnosed with cancer, $70 \%$ (fourteen cases) had Candida spp. This result is higher thanthose

obtained by Schelenz et al. (2011), who found a prevalence of oral yeast colonization in 56.8\% (227/400) of cancerpatients. C. albicans was also the predominant $(74 \%)$ specie in this research, followed by C. glabrata $(11.5 \%)$, C. tropicalis (2.6\%), C. krusei (2.6\%) and C. parapsilosis $(1.9 \%)$. Finally, this and others authors reported a significant increased risk of clinical oral fungal infection during cancer therapy (Lalla et al., 2010; Schelenz et al., 2011).

In conclusion, the present study showed that hospitalized patients have 6.73 more chances to have Candida spp. compared with the non-hospitalized individuals and 3.88 more chances to have Candida albicans. Besides that, the prevalence of Candida spp., is higher in those hospitalized patients under antibiotic therapy ( $p$-value $<0.0001$ ). This finding deserves an important attention in the clinical and medical area due to the association of the frequency of the gender Candida spp. in hospitalized patients, since the infection caused by this fungus is associated with a higher severity of clinical response and by the immunosuppression that these individuals have.

\section{References}

AL THAQAFI, A.H., FARAHAT, F.M., AL HARBI, M.I., AL AMRI, A.F. and PERFECT, J.R., 2014. Predictors and outcomes of Candida bloodstream infection: eight-year surveillance, western
Saudi Arabia. International Journal of Infectious Diseases, vol. 21, pp. 5-9. PMid:24468816. http://dx.doi.org/10.1016/j. ijid.2013.12.012

ARAÚJO, C.R.D, MIRANDA, K.C., PASSOS, X.S., SOUZA, L.K.H., SILVA, M.D.R.R., and FERNANDES, O.D.F.L., 2005. Identificação das leveduras do gênero candida por métodos manuais convencionais e pelo método cromógeno chromagar ${ }^{\mathrm{TM}}$ candida. Repositorio Institucional UFG, vol. 34, no. 1, p. 37-42.

BODinEAU, A., FOLLIGUET, M. and SÉGUIER, S., 2009. Tissular senescence and modifications of oral ecosystem in the elderly: risk factors for mucosal pathologies. Current Aging Science Journal, vol. 2, no. 2, pp. 109-120. PMid:20021405. http://dx.doi.org/10.2174/1874609810902020109.

CANTÓN, E., PEMÁN, J., SASTRE, M., ROMERO, M. and ESPINEL-INGROFF, A., 2006. Killing kinetics of caspofungin, micafunigin, and amphotericin B against Candida guilliermondii. Antimicrobial Agents and Chemotherapy, vol. 50, no. 8, pp. 28292832. PMid:16870779. http://dx.doi.org/10.1128/AAC.00524-06.

DOMANESCHI, C., MASSARENTE, D.B., FREITAS, R.S., MARQUES, H.H.S., PAULA, C.R., MIGLIARI, D.A. and ANTUNES, J.L.F., 2011. Oral colonization by Candida species in AIDS pediatric Patients. Journal of Oral Diseases, vol. 17, no. 4, pp. 393-398. PMid:21114590. http://dx.doi.org/10.1111/j.16010825.2010.01765.x.

GONÇALVES, C.L., MOTA, F.V., MENDES, J.F., FERREIRA, G.F., VIEIRA, J.N., PEREIRA, E. and NASCENTE, P.S., 2015. Leveduras isoladas em unidade de terapia intensiva do sul do Rio Grande do Sul, Brasil. Revista de Epidemiologia e Controle de Infecção, vol. 5, no. 2, pp. 111-112. http://dx.doi.org/10.17058/ reci.v5i2.5678.

GRIMOUD, A.M., MARTY, N., BOCQUET, H., ANDRIEU, S., LODTER, J.P. and CHABANON, G., 2003. Colonization of the oral cavity by Candida species: risk factors in long-term geriatric care. Journal of Oral Science, vol. 45, no. 1, pp. 51-55. PMid:12816366. http://dx.doi.org/10.2334/josnusd.45.51.

HEO, S.M., SUNG, R.S., SCANNAPIECO, F.A. and HAASE, E.M., 2011. Genetic relationships between Candida albicans strains isolated from dental plaque, trachea, and bronchoalveolar lavage fluid from mechanically ventilated intensive care unit patients. Journal of Oral Microbiology, vol. 3, no. 1, pp. 6362. PMid:21731911. http://dx.doi.org/10.3402/jom.v3i0.6362.

HINRICHSEN, S.L., FALCÃO, E., VILELLA, T.A., RÊGO, L., LIRA, C., ALMEIDA, L., MARTINS, M., ARAÚJO, C., DUARTE, M. and LOPES, G., 2009. Candida isolates in tertiary hospitals in northeastern Brazil. Brazilian Journal of Microbiology, vol. 40, no. 2, pp. 325-328. PMid:24031366. http://dx.doi.org/10.1590/ S1517-83822009000200021.

HUBE, B., 2004. From commensal to pathogen: stage- and tissuespecifc gene expression of Candida albicans. Current Opinion in Microbiology, vol. 7, no. 4, pp. 336-341. PMid:15288621. http:// dx.doi.org/10.1016/j.mib.2004.06.003.

KRCMERY JUNIOR, V., ORAVCOVA, E., SPANIK, S., MRAZOVASTUDENA, M., TRUPL, J., KUNOVA, A., STOPKOVA-GREY, K., KUKUCKOVA, E., KRUPOVA, I., DEMITROVICOVA, A. and KRALOVICOVA, K., 1998. Nosocomial breakthrough fungaemia during antifungal prophylaxis or empirical antifungal therapy in 41 cancer patients receiving antineoplastic chemotherapy: analysis of a etiology risk factors and outcome. The Journal of Antimicrobial Chemotherapy, vol. 41, no. 3, pp. 373-380. PMid:9578164. http:// dx.doi.org/10.1093/jac/41.3.373. 
LALLA, R.V., LATORTUE, M.C., HONG, C.H., ARIYAWARDANA, A., D'AMATO-PALUMBO, S., FISCHER, D.J., MARTOF, A., NICOLATOU-GALITIS, O., PATTON, L.L., ELTING, L.S., SPIJKERVET, F.K., BRENNAN, M.T., FUNGAL INFECTIONS SECTION, ORAL CARE STUDY GROUP, MULTINATIONAL ASSOCIATION OF SUPPORTIVE CARE IN CANCER and INTERNATIONAL SOCIETY OF ORAL ONCOLOGY, 2010. A systematic review of oral fungal infections in patients receiving cancer therapy. Supportive Care in Cancer, vol. 18, no. 8, pp. 985-992. PMid:20449755. http://dx.doi.org/10.1007/ s00520-010-0892-z.

LASS-FLÖRL, C., 2009. The changing face of epidemiology of invasive fungal disease in Europe. Mycoses, vol. 52, no. 3, pp. 197-205. PMid:19391253. http://dx.doi.org/10.1111/j.14390507.2009.01691.x

LUND, R.G., NASCENTE, P.S., ETGES, A., RIBEIRO, G.A., ROSALEN, P.L. and PINO, F.A., 2010. Occurrence, isolation and differentiation of Candida spp. and prevalence of variables associated to chronic atrophic candidiasis. Mycoses, vol. 53, no. 3, pp. 232-238. PMid:19389071. http://dx.doi.org/10.1111/j.14390507.2009.01697.x

MEURMAN, J.H. and HÄMÄLÄINEN, P., 2006. Oral health and morbidity: implication of oral infections on the elderly. Gerodontology, vol. 23, no. 1, pp. 3-16. PMid:16433636. http:// dx.doi.org/10.1111/j.1741-2358.2006.00102.x.

MÍMICA, L.M.J., UEDA, S.M.Y., MARTINO, M.D.V., NAVARINI, A. and MARTINI, I.J., 2009. Candida infection diagnosis: evaluation of Candida species identification and characterization of susceptibility profile. Jornal Brasileiro de Patologia e Medicina Laboratorial, vol. 45, pp. 17-23.

MOREIRA, D., SPOLIDÓRIO, D.M.P., RODRIGUES, J.A.O., BORIOLLO, M.F.G., PEREIRA, C.V., ROSA, E.A.R. and HÖFLING, J.F., 2001. Candida spp. biotypes in the oral cavity of school children from different socioeconomic categories in Piracicaba - SP, Brazil. Pesquisa Odontologica Brasileira, vol. 15, no. 3, pp. 187-195. PMid:11705265. http://dx.doi.org/10.1590/ S1517-74912001000300003.

MORIS, D.V., MELHEM, M.S.C., MARTINS, M.A. and MENDES, R.P., 2008. Oral Candida spp. Colonization in human immunodeficiency virus-infected individuals. The Journal of Venomous Animals and Toxins Including Tropical Diseases, vol. 14, no. 2, pp. 224-257. http://dx.doi.org/10.1590/S167891992008000200004

MOTTA, A.L., ALMEIDA, G.M., ALMEIDA JÚNIOR, J.N., BURATTINI, M.N. and ROSSI, F., 2010. Candidemia epidemiology and susceptibility profile in the largest Brazilian teaching hospital complex. The Brazilian Journal of Infectious Diseases, vol. 14, no. 5, pp. 441-448. PMid:21221471. http://dx.doi.org/10.1016/ S1413-8670(10)70091-X.

MOYES, D.L. and NAGLIK, J.R., 2011. Mucosal Immunity and Candida albicansInfection. Clinical \& Developmental Immunology, vol. 2011, pp. 346307. PMid:21776285. http:// dx.doi.org/10.1155/2011/346307.

NAGLIK, J.R. and MOYES, D., 2011. Epithelial cell innate response to Candida albicans. Advances in Dental Research, vol. 23, no. 1, pp. 50-55. PMid:21441481. http://dx.doi. org/10.1177/0022034511399285

NAGLIK, J.R., CHALLACOMBE, S.J. and HUBE, B., 2003. Candida albicans secreted aspartyl proteinases in virulence and pathogenesis. Microbiology and Molecular Biology Reviews, vol. 67, no. 3, pp. 400-428. PMid:12966142. http://dx.doi.org/10.1128/ MMBR.67.3.400-428.2003.

PFALLER, M.A. and DIEKEMA, D.J., 2007. Epidemiology of invasive candidiasis: a persistent public health problem. Clinical Microbiology Reviews, vol. 20, no. 1, pp. 133-163. PMid:17223626. http://dx.doi.org/10.1128/CMR.00029-06.

RIBEIRO, E.L., SCROFERNEKER, M.L., CAVALHAES, M.S., CAMPOS, C.C., NAGATO, G.M., SOUZA, N.A., FERREIRA, W.M., CARDOSO, C.G., DIAS, S.M., PIMENTA, F.C. and TOLEDO, O.A., 2006. Phenotypic aspects of oral strains of Candida albicans in children with down's syndrome. Brazilian Journal of Biology = Revista Brasileira de Biologia, vol. 66, no. 3, pp. 939-944. PMid:17119842. http://dx.doi.org/10.1590/ S1519-69842006000500020.

SANTANA, D.P., RIBEIRO, E.L., MENEZES, A.C.S. and NAVES, P.L.F., 2013. New approaches on virulence factors of Candida albicans. Revista de Ciências Médicas e Biológicas, vol. 12, pp. 229-233.

SAVASTANO, C., SILVA, E.O., GONÇALVES, L.L., NERY, J.M., SILVA, N.C. and DIAS, A.L., 2016. Candida glabrata among Candida spp. from environmental health practitioners of a Brazilian Hospital. Brazilian Journal of Microbiology, vol. 47, no. 2, pp. 367-372. PMid:26991302. http://dx.doi.org/10.1016/j. bjm.2015.05.001.

SCHELENZ, S., ABDALLAH, S., GRAY, G., STUBBINGS, H., GOW, I., BAKER, P. and HUNTER, P.R., 2011. Epidemiology of oral yeast colonization and infection in patients with hematological malignancies, head neck and solid tumors. Journal of Oral Pathology \& Medicine, vol. 40, no. 1, pp. 83-89. PMid:20923440. http://dx.doi.org/10.1111/j.1600-0714.2010.00937.x.

SILVA, A.K.F., LISBOA, J.E.S., BARBOSA, M.P.C.S. and LIMA, A.F., 2014. Infecções urinárias nosocomiais causadas por fungos do gênero Candida: uma revisão. Ciencias Biológicas e da Saúde, vol. 2 , no. 1 , pp. $45-57$.

SIMÕES, R.J., FONSECA, P. and FIGUEIRAL, M.H., 2013. Oral infections by Candida spp. Odontologia Clínico-Cientifica, vol. 12, no. 1, pp. 19-22.

SINGH, N., 2001. Trends in the epidemiology of opportunistic fungal infections: predisposing factors and the impact of antimicrobial use practices. Clinical Infectious Diseases, vol. 33, no. 10, pp. 1692-1696. PMid:11641825. http://dx.doi.org/10.1086/323895.

SOLL, D.R., LOCKHART, S.R. and ZHAO, R., 2003. Mating and virulence of Candida albicans. The Mycologist, vol. 17, no. 2, pp. 64-69. http://dx.doi.org/10.1017/S0269915X03002052.

SPOLIDORIO, D.M., BORIOLLO, M.F., ESTRELA, C. and SPOLIDORIO, L.C., 2009. Diferentes métodos fenotípicos para isolamento e identificação de espécies de Candida. ROBRAC, vol. 45 , pp. $18-26$

ST-GERMAIN, G., LAVERDIÈRE, M., PELLETIER, R., RENÉ, P., BOURGAULT, A.M., LEMIEUX, C. and LIBMAN, M., 2008. Epidemiology and antifungal susceptibility of bloodstream Candida isolates in Quebec: Report on 453 cases between 2003 and 2005. Canadian Journal of Infections Diseases and Medical Microbiology, vol. 19, no. 1, pp. 55-62. PMid:19145263. http:// dx.doi.org/10.1155/2008/634046. 